\title{
Protein Restriction during Pregnancy Induces Hypertension and Impairs Endothelium-Dependent Vascular Function in Adult Female Offspring
}

\author{
Kunju Sathishkumar Rebekah Elkins Uma Yallampalli Chandra Yallampalli \\ Department of Obstetrics and Gynecology, University of Texas Medical Branch, Galveston, Tex., USA
}

\section{Key Words}

Mean arterial blood pressure $\cdot$ Endothelium $\cdot$ Nitric oxide $\cdot$ Fetal programming $\cdot$ Pregnancy $\cdot$ Vascular smooth muscle $\cdot$ Relaxation $\cdot$ Constriction $\cdot$ Hypertension

\begin{abstract}
Intrauterine undernutrition plays a role in the development of adult hypertension. Most studies are done in male offspring to delineate the mechanisms whereby blood pressure may be raised; however, the vascular mechanisms involved in female offspring are unclear. Female offspring of pregnant Sprague-Dawley rats fed either a control $(C ; 18 \%)$ or a low-protein (LP; 6\%) diet during pregnancy were used. Birth weight and later growth were markedly lower in LP than in C offspring. LP offspring exhibited impaired estrous cyclicity with increased mean arterial pressure. Hypotensive response to acetylcholine (ACh) and the hypertensive response to phenylephrine (PE) were greater in LP than in C rats. N-nitro-L-arginine methyl ester (L-NAME) induced greater hypertensive responses in $C$ than in LP rats. Endotheliumintact mesenteric arteries from LP offspring exhibited increased contractile responses to $P E$ and reduced vasodilation in response to $\mathrm{ACh}$. In endothelium-denuded arteries, relaxation responses to sodium nitroprusside were similar in both groups. Basal and ACh-induced increase in vascular nitrite/ nitrate production was lower in LP than in C offspring. LNAME or 1H-1,2,4-oxadiazolo-4,3-quinoxalin-1-one inhibited $A C h$ relaxations and enhanced PE contractions in $C$ off-
\end{abstract}

spring, but had minimal effect in LP rats. The decreased NO-mediated vascular response might explain the increased vascular contraction and arterial pressure in female offspring with low birth weight.

Copyright $\odot 2008$ S. Karger AG, Basel

\section{Introduction}

Epidemiologic studies have shown that low birth weight is associated with increased risk of cardiovascular (CV) disease in adulthood and have led to the hypothesis that the fetal CV system undergoes programming in utero in response to unbalanced maternal nutrition [1-6]. These human studies are strongly supported by animal experiments showing that a severe but balanced limitation of fetal substrate supply retards fetal growth and induces CV dysfunction and hypertension [7-10]. The hypothesis of developmental origins of disease proposes that maternal undernutrition causes permanent changes in structure and function of tissues and organs, resulting in CV and related disorders in the offspring $[11,12]$.

The mechanisms involved in the programming of adult hypertension have remained unknown, although a significant correlation between adverse intrauterine environments and alterations of vascular or endothelial function has been reported $[10,13,14]$. In addition, a possible role for the renin-angiotensin system $[15,16]$, the kidney $[17,18]$ and stress-induced stimulation of the hy-

Dr. Chandra Yallampalli

Department of Obstetrics and Gynecology, University of Texas Medical Branch

301 University Blvd., MRB, 11.138, Rt. 1062

Galveston, TX 77555-1062 (USA)

Tel. +1 409772 7592, Fax +1 409747 0475, E-Mail chyallam@utmb.edu 
pothalamic-pituitary-adrenal axis [19-21] has been identified. Studies of fetal programming have shown that there are gender-related differences in the occurrence of $\mathrm{CV}$ dysfunction in humans at various ages [22]. Some animal studies have also demonstrated that hypertension or vascular dysfunction induced by a maternal low-protein diet is more pronounced in males than in females [13, 23, 24]. Most studies have used male animals to explain the potential mechanisms through which hypertension may be initiated by fetal undernutrition. The reasons for the paucity of studies in females may be that females develop moderate and less consistent postnatal hypertension [24]. It is shown that the severity of hypertension in females depends on the extent of maternal protein restriction and the age at which the offspring are examined $[25,26]$. Our laboratory has shown that $66 \%$ maternal protein restriction consistently results in development of hypertension at $\geq 6$ months of age in female offspring while the males are hypertensive as early as 2 months [27]. The delay in development of hypertension in the females is attributed to the presence of sex steroid, e.g. estrogen [26]. It is well known that adequate levels of estrogen are essential in modulating vascular function through the release of endothelium-derived relaxant factors such as nitric oxide (NO) [28-30]. We and others have shown that there is a reduction in estrogen levels in the hypertensive female offspring $[13,27]$. Endothelial dysfunction consequent to decreased estrogen levels or due to other factors may play a role in the development of hypertension in the female offspring of nutritionally restricted dams. Previous studies have reported that endothelium-dependent relaxation was blunted in conduit arteries (aorta) from the adult female offspring of pregnant rat dams fed a globally restricted diet [13]. Also, the endothelial NO synthase (eNOS) activity was shown to be reduced in these animals [13]. However, the functional consequences of low protein on resistance vessels, which are the actual determinants of blood pressure, in female offspring are currently not known. The purpose of this study was to test the hypothesis that intrauterine fetal growth restriction due to protein restriction results in low-birth-weight offspring, female offspring having impaired estrous cyclicity and exhibiting reduced endothelium-dependent vascular relaxation, enhanced vascular contraction and hypertension, specifically during their late adult life. To test this hypothesis, we studied vascular function in vivo and contraction and relaxant (endothelium-dependent and -independent) responses ex vivo in small mesenteric arteries from rat female offspring at 1 year of age.

\section{Methods}

\section{Animals}

All procedures were approved by the Animal Care and Use Committee at the University of Texas Medical Branch and were in accordance with those published by the US National Institutes of Health Guide for the Care and Use of Laboratory Animals (NIH Publication No. 85-23, revised 1996). Virgin female SpragueDawley rats (Harlan Sprague Dawley, Houston, Tex., USA) weighing between 175 and $225 \mathrm{~g}$ (4 months old) were mated with male Sprague-Dawley rats; conception was confirmed by observation of a vaginal copulation plug or the presence of sperm in the vaginal flush. Pregnant rats were randomly divided into two dietary groups, housed individually and fed a control (C, 18\% casein) or low protein (LP, 6\% casein) diet throughout pregnancy. The isocaloric low-protein and normal-protein diets were obtained from Harlan Teklad (Madison, Wisc., USA). The composition of the diets for the 2 groups, except for the protein content, was identical as previously described [31]. All pregnant rats were allowed to deliver at term. At delivery, all dams were placed on the normal diet and the pups were weaned to the normal diet at 21 days of age and maintained on that diet thereafter. Offspring of C and LP pregnant rats were referred to as the $\mathrm{C}$ group and LP group, respectively. The litter sizes and birth weights of $\mathrm{C}$ and LP pups were recorded within $12 \mathrm{~h}$ after delivery and weighed once a week thereafter. The animals were housed in a room with a controlled temperature and a 12-hour:12-hour light-dark cycle.

\section{Estrous Cyclicity}

Estrous cyclicity in both groups of rats was assessed by daily vaginal lavages (smears). Monitoring began on postnatal day 150 and continued for 17 days. Smears were taken between 09.00 and $11.00 \mathrm{~h}$ each morning, examined unstained, by light microscopy $(\times 20)$, and assessed for relative abundance of leukocytes, nucleated epithelial cells and cornified epithelial cells. Six animals each from the $\mathrm{C}$ and LP groups were assessed for estrous cyclicity. Cyclicity was assessed by calculating the average number of estrous cycles observed in each group over the monitoring period (i.e. total number of estrous cycles divided by the number of rats in that group).

\section{Assessment of Vascular Function in vivo}

Mean arterial pressure (MAP) was determined in conscious rats at 1 year of age. Rats were anesthetized with ketamine (45 $\mathrm{mg} / \mathrm{kg}$ body weight; Burns Veterinary Supply, Westbury, N.Y., USA) and xylazine ( $5 \mathrm{mg} / \mathrm{kg}$ body weight; Burns Veterinary Supply). The jugular vein and carotid artery were cannulated with polyethylene tubing (PE-50; Becton Dickinson, Sparks, Md., USA). After the animals had recovered from anesthesia, the carotid cannula that was filled with heparinized saline $\left(50 \mathrm{U} \cdot \mathrm{ml}^{-1}\right)$ was connected to a pressure transducer to record MAP using the DBP001 direct blood pressure system (Kent Scientific, Litchfield, Conn., USA). The jugular vein cannula was used to administer drugs as an intravenous (i.v.) bolus. MAP was monitored continuously for $30 \mathrm{~min}$ before administration of any drugs. Dose-dependent hypotensive responses to acetylcholine (ACh; 0.03, 0.1, 0.3, $1,3 \mu \mathrm{g} \cdot \mathrm{kg}^{-1}$ i.v.) and hypertensive responses to phenylephrine (PE; $1,3,10,30 \mu \mathrm{g} \cdot \mathrm{kg}^{-1}$ i.v.) were obtained in both $\mathrm{C}$ and $\mathrm{LP}$ rats. eNOS was inhibited with the administration of N-nitro-L-arginine methyl ester (L-NAME, $50 \mathrm{mg} \cdot \mathrm{kg}^{-1}$ i.v.) to rats in both groups 
to determine the relative contribution of the endothelium in maintaining the basal MAP. Enough time was allowed between responses for MAP to recover to the resting level.

\section{Preparation of Mesenteric Arteries}

The rats were sacrificed by $\mathrm{CO}_{2}$ inhalation and the mesenteric arcade was excised and immersed in oxygenated Krebs physiological salt solution (KPSS) [6]: $\mathrm{NaCl}, 119 ; \mathrm{KCl}, 4.7 ; \mathrm{CaCl}_{2}, 2.5$; $\mathrm{MgSO}_{4}, 1.17 ; \mathrm{NaHCO}_{3}, 25 ; \mathrm{KH}_{2} \mathrm{PO}_{4}, 1.18$; EDTA, 0.026; and Dglucose, 5.5. Small mesenteric arteries were dissected free of connective tissue and mounted using tungsten wires on a wire myograph (Kent Scientific) to record isometric tension. The tissues were incubated for $15 \mathrm{~min}$ in $\mathrm{KPSS}$ at $37^{\circ} \mathrm{C}$, which was gassed with $95 \% \mathrm{O}_{2}$ and $5 \% \mathrm{CO}_{2}$ to maintain $\mathrm{pH}$ 7.4. The segments were initially loaded to an optimum stretch, which was previously determined by using high- $\mathrm{K}^{+}$physiological solution $(80 \mathrm{mmol} / \mathrm{l})$ as the contracting agent after applying different passive tensions. The initial stretch and the length of the segments $(2 \mathrm{~mm})$ were consistently maintained across all arterial rings of either group. For endothelium-intact mesenteric rings, extreme care was taken to avoid injury to the endothelium. For endothelium-denuded mesenteric rings, the endothelium was removed by gently rubbing the ring interior with tungsten wire. Removal of the endothelium was verified by the absence of ACh relaxation in tissues precontracted by a submaximal concentration of PE.

\section{Assessment of Vascular Reactivity in Mesenteric Arteries}

Endothelium-intact mesenteric arterial rings were stimulated with increasing concentrations of $\mathrm{PE}$, and concentration-contraction curves were constructed. The PE concentration used for precontraction was that required to produce $80 \%$ of the maximal response $\left(\mathrm{pEC}_{80}\right)$. Endothelium-dependent relaxation was assessed by ACh $\left(10^{-9}-10^{-5} \mathrm{~mol} / \mathrm{l}\right)$-induced relaxation in PE-precontracted arteries. Endothelium-independent relaxation was determined by sodium nitroprusside (SNP, $10^{-9}-10^{-6} \mathrm{~mol} / \mathrm{l}$ ) induced relaxation in $\mathrm{PE}$-precontracted endothelium-denuded arteries. In other experiments, the tissues were pretreated for 30 min with L-NAME $\left(10^{-4} \mathrm{~mol} / \mathrm{l}\right)$ to inhibit eNOS or with $1 \mathrm{H}-1,2,4$ oxadiazolo-4,3-quinoxalin-1-one (ODQ, $10^{-5} \mathrm{~mol} / \mathrm{l}$, Sigma) to inhibit cGMP production in smooth muscle and the effects on $\mathrm{PE}$ contraction and ACh-induced relaxation of $\mathrm{PE}$ contraction were measured.

\section{Nitrite/Nitrate Production}

Endothelium-intact mesenteric rings were placed in wells of 24-well plates containing $500 \mu \mathrm{KPSS}$ aerated with $95 \% \mathrm{O}_{2}$ and $5 \% \mathrm{CO}_{2}$ at $37^{\circ} \mathrm{C}$. Samples for basal accumulation of nitrite $\left(\mathrm{NO}_{2}^{-}\right)$ formed from released NO were first taken. The KPSS was replaced and the arterial rings were stimulated with ACh $\left(10^{-7}\right.$ or $10^{-5}$ ) for $5 \mathrm{~min}$. The rings were rapidly removed, dabbed dry with filter paper and weighed. The incubation solutions were assayed for the stable end product of $\mathrm{NO}, \mathrm{NO}_{2}^{-}$. In brief, samples of incubation solution $(80 \mu \mathrm{l})$ were mixed in a 96 -well microtiter plate with $100 \mu \mathrm{l}$ of the Griess reagent (Sigma). The chromophore generated by the reaction with $\mathrm{NO}_{2}^{-}$was detected spectrophotometrically $(540 \mathrm{~nm})$ on a microtiter plate reader (Spectramax, Molecular Devices, Sunnyvale, Calif., USA). The concentration of $\mathrm{NO}_{2}^{-}$was calculated from a calibration curve constructed with known concentrations of $\mathrm{NaNO}_{2}$.

Reduced Endothelium-Dependent

Relaxation in Female Offspring
Table 1. Body weight, litter size, estrous cyclicity and MAP in the $\mathrm{C}$ and LP groups

\begin{tabular}{lcc}
\hline & \multicolumn{1}{c}{ C group } & \multicolumn{1}{c}{ LP group } \\
\hline Gestational days ( $\mathrm{n}=4-5)$ & $22 \pm 0.3$ & $22 \pm 0.8$ \\
Weight $(\mathrm{n}=28$-32 per group), $\mathrm{g}$ & & \\
$\quad$ At birth & $6.7 \pm 0.09$ & $4.8 \pm 0.10^{*}$ \\
$\quad$ At weaning & $49.1 \pm 1.33$ & $40.7 \pm 1.74^{*}$ \\
$\quad$ At 8 weeks & $277.1 \pm 2.72$ & $266.0 \pm 4.17^{*}$ \\
$\quad$ At 1 year & $11 \pm 1$ & $11 \pm 1$ \\
Litter size ( $=4-5)$ & & \\
Number of observed cycles $\quad(\mathrm{n}=6$ per group) & 3 & $0.5^{*}$ \\
Cycling, \% & 100 & $17^{*}$ \\
MAP at 1 year (n=7-8), mm Hg & $104.7 \pm 3.13$ & $133.9 \pm 4.05^{*}$ \\
\hline
\end{tabular}

Values are expressed as means \pm SEM.

${ }^{*} \mathrm{p}<0.05$ compared to the $\mathrm{C}$ group.

Drugs and Chemicals

Stock solutions of PE, ACh, SNP, and L-NAME (Sigma) were prepared in distilled water. ODQ was dissolved in dimethylsulfoxide. The final concentration of dimethylsulfoxide in solution was $<0.1 \%$. All other chemicals were of reagent grade or better.

Calculation and Statistical Analysis

Data are presented as means \pm SEM. Statistical analysis was performed using a two-way ANOVA followed by the Bonferroni post hoc test on all dose-response curves and the unpaired Student's $t$ test for comparison of single observation between the $\mathrm{C}$ and LP groups. Because the baseline MAPs were different in the $\mathrm{C}$ and LP groups, the hypotensive/hypertensive responses were calculated as percent decrease/increase in MAP with respect to the baseline MAP before each response. We and others have shown that the dose-dependent percent change in MAP after agonists is not related to the baseline MAP $[32,33]$. Contraction responses to $\mathrm{PE}$ were calculated as percent of its maximal contraction. Relaxant responses to ACh were calculated as percent inhibition of the PE-induced contraction. Maximal responses and half maximal effective concentration values were then obtained. Half maximal effective concentrations were determined by regression analysis and expressed as negative log-molar concentration. Data analysis was done using GraphPad Prism for Windows (GraphPad Software, San Diego, Calif., USA). Data from several vascular rings of the same rat were averaged and presented as the datum for 1 rat, with the $n$ value representing the number of rats. Differences are considered statistically significant at $\mathrm{p}<0.05$.

\section{Results}

\section{Offspring Birth Weights}

The birth weight of $C$ rats was $6.7 \pm 0.08 \mathrm{~g}$ and was significantly reduced in LP rats $(4.7 \pm 0.1 \mathrm{~g})$. Both $C$ and LP offspring showed significant increases in body weight 


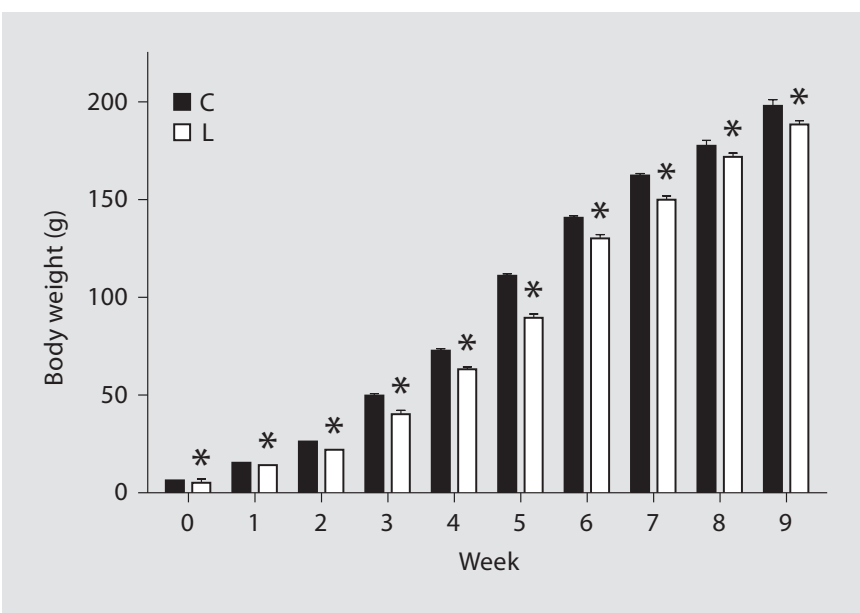

Fig. 1. Body weight gain from birth to 9 weeks of age in offspring of the C and LP groups. Values are expressed as mean \pm SEM. ${ }^{*} \mathrm{p}<0.05$ compared with the $\mathrm{C}$ group.

with age. However, the growth curves of the two groups were significantly different and were parallel through adulthood (fig. 1). The body weight at the time of terminal study (1 year) was significantly lower in LP offspring than in $C$ rats $(266.0 \pm 4.2$ vs. $277.1 \pm 2.7 \mathrm{~g})$. The length of gestation and number of pups per litter were not different among groups (table 1).

\section{Estrous Cyclicity}

Assessment of estrous cyclicity revealed a significant decrease in the number of observed estrous cycles over a 17-day period in the LP group compared to $\mathrm{C}$ rats (table 1). The 6 rats in the $C$ group totaled 18 estrous cycles (average $=3$ ), while in the LP group only a total of 3 estrous cycles were observed (average $=0.5)$ (table 1). Although few animals showed extended cycle length, most rats had already stopped cycling in the LP group.

\section{Blood Pressure Measurement}

Baseline MAP measured in 1-year-old rats was significantly higher in LP rats when compared with the C group $(133.9 \pm 4.05$ vs. $104.7 \pm 3.13 \mathrm{~mm} \mathrm{Hg})$. We found that ACh evoked a concentration-dependent decrease in MAP that was attenuated in LP rats (fig. 2a). Administration of $\mathrm{PE}$ evoked a concentration-dependent hypertensive response that was more pronounced in LP offspring compared to $\mathrm{C}$ rats (fig. 2b). Acute administration of the eNOS inhibitor, L-NAME, induced significantly greater hypertensive responses in $\mathrm{C}(60.0 \pm 2.64 \%)$ than in LP offspring (30.6 $\pm 3.00 \%)$.
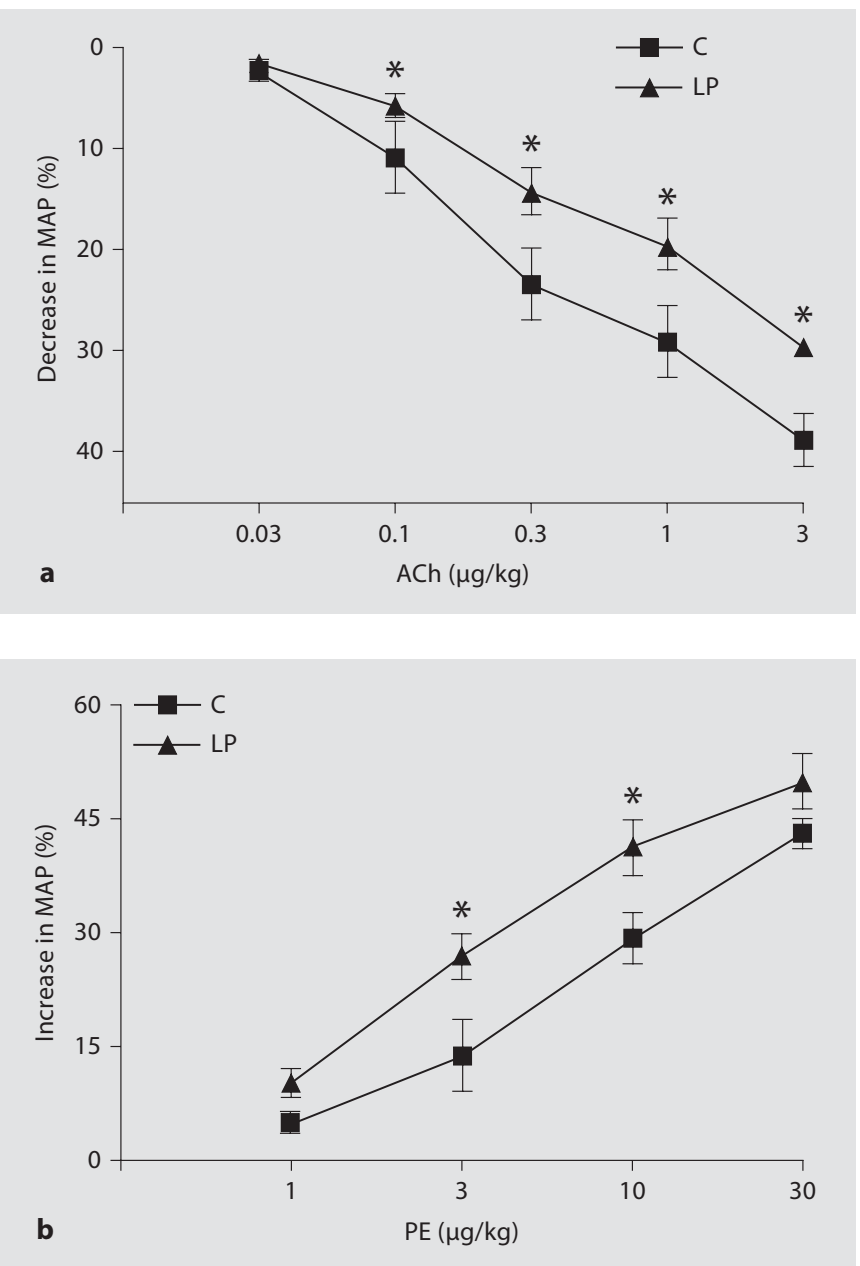

Fig. 2. a Dose-response curve for ACh-evoked hypotension in $\mathrm{C}$ and LP rats. Conscious female rats were administered increasing concentrations of ACh as intravenous bolus doses. Hypotensive responses were calculated as percent decrease in MAP with respect to baseline MAP before each response. Values are expressed as means \pm SEM of 3 or 4 animals. ${ }^{*} \mathrm{p}<0.05$ compared with the C group. $\mathbf{b}$ Dose-response curve for PE-evoked hypertension in $\mathrm{C}$ and LP rats. Conscious female rats were administered increasing concentrations of PE as intravenous bolus doses. Hypertensive responses were calculated as percent increase in MAP with respect to baseline MAP before each response. Values are expressed as means \pm SEM of 3 or 4 animals. ${ }^{*} \mathrm{p}<0.05$ compared with the C group.

\section{Contractile Responses}

In endothelium-intact mesenteric rings from both groups of rats, PE caused concentration-dependent increases in contraction. When the PE response was presented as the percentage of maximum $\mathrm{PE}$ contraction, the median effective concentration $\left(\mathrm{ED}_{50}\right)$ of $\mathrm{PE}$ in $\mathrm{C}$ rats was greater than that in LP rats $(5.4 \pm 0.05$ vs. $5.8 \pm$ 


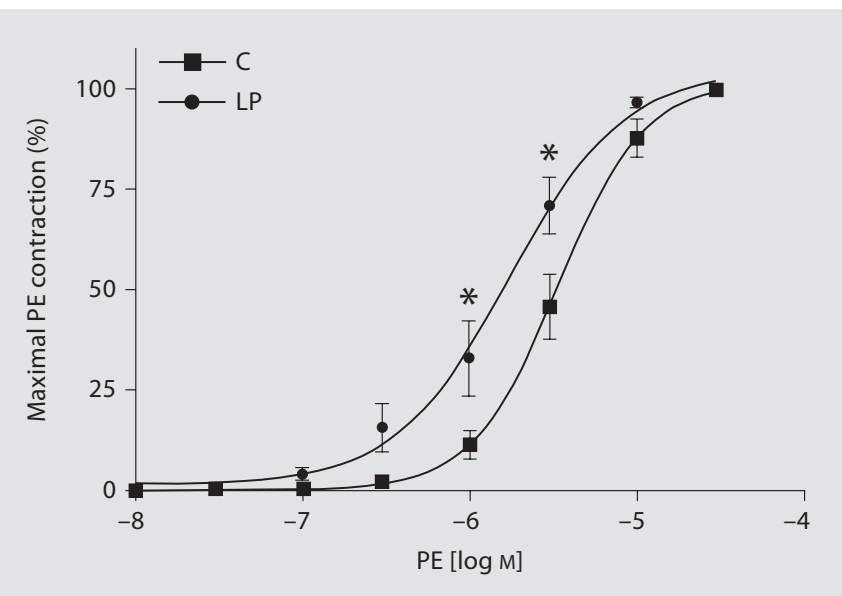

Fig. 3. $P E$-induced contraction in mesenteric arterial rings of $\mathrm{C}$ and LP rats. Endothelium-intact mesenteric arterial rings were incubated in normal KPSS and then stimulated with increasing concentrations of PE. PE contraction was measured and presented as percentage of maximum PE contraction (semilog plot). Data points represent means \pm SEM of measurements in 10-12 mesenteric arterial rings from $5-6$ rats of each group. ${ }^{*} \mathrm{p}<0.05 \mathrm{com}-$ pared with $\mathrm{C}$ rats.

$0.12 \mathrm{~mol} / \mathrm{l}$; fig. 3 , table 2). This shows that $\mathrm{PE}$ was more potent in producing contractions in LP rats than in $\mathrm{C}$ animals.

Pretreatment with L-NAME for $30 \mathrm{~min}$ to inhibit eNOS activity significantly enhanced the maximal PEinduced contraction in LP rats (116.6 $\pm 2.54 \%$; fig. $4 \mathrm{~b}$, table 2) and to a greater extent in C rats (136.6 $\pm 5.95 \%$; fig. 4a, table 2). Also, plotting the PE response as a percentage of maximum and calculation of the $\mathrm{PE} \mathrm{ED}_{50}$ showed that $\mathrm{PE}$ was slightly more potent (but the difference was not statistically significant, $\mathrm{p}=0.46$ ) in causing contraction in L-NAME-pretreated than in nontreated arterial rings of LP rats (fig. $4 \mathrm{~b}$, table 2). PE was far more potent in causing contraction in L-NAMEtreated than non-treated vascular rings of $\mathrm{C}$ rats (fig. $4 \mathrm{a}$, table 2).

Similarly, in endothelium-intact vascular rings, pretreatment with ODQ for 30 min to inhibit cGMP production in smooth muscle significantly enhanced the maximal PE-induced contraction in LP rats (119.7 \pm 3.18\%; fig. 4 b, table 2$)$ and to a greater extent in $C$ rats (136.5 \pm 5.73\%; fig. 4a, table 2). PE was slightly more potent (but the difference is not statistically significant, $p=0.27$ ) in producing contractions in ODQ-treated arterial rings of $\mathrm{LP}$ rats than in $\mathrm{C}$ animals (fig. $4 \mathrm{a}$, table 2).

Reduced Endothelium-Dependent Relaxation in Female Offspring
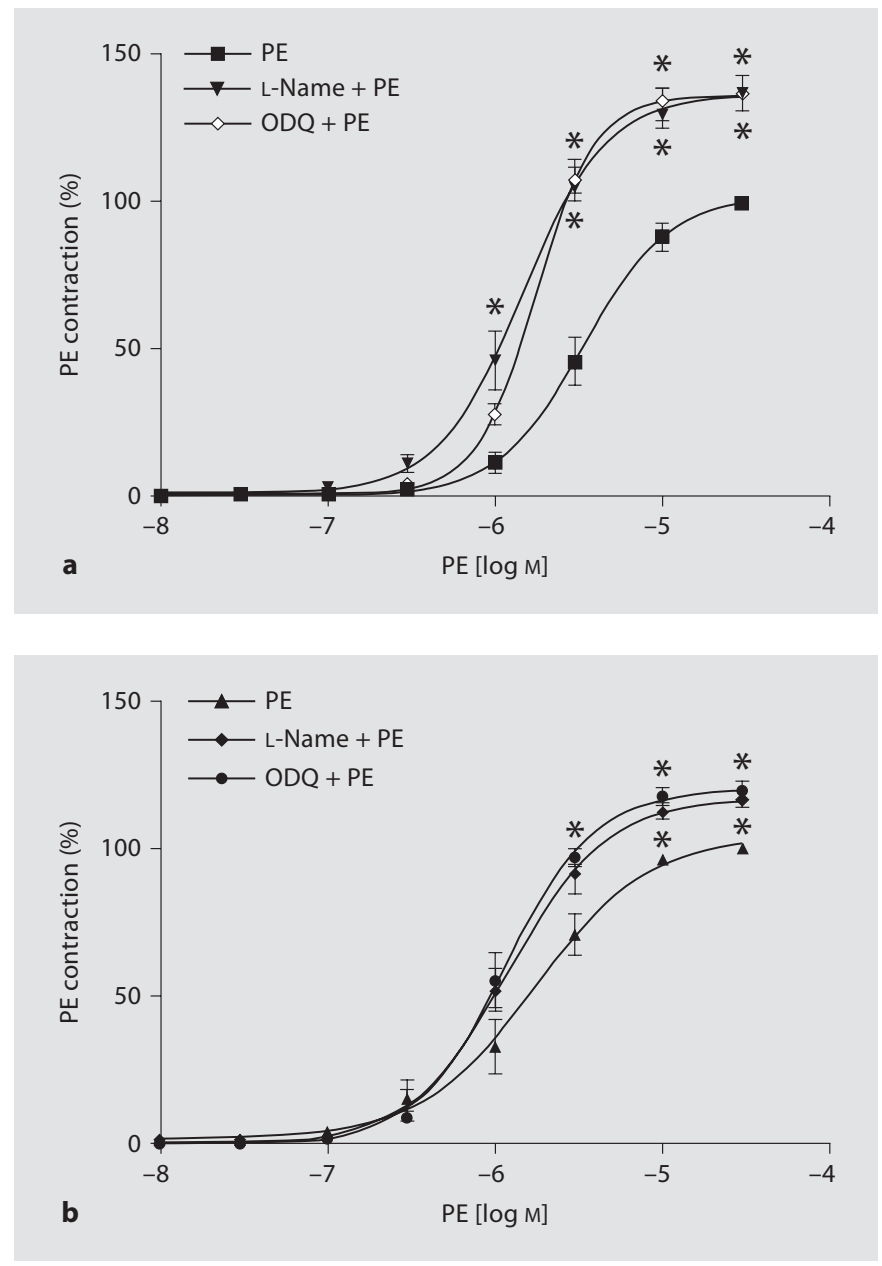

Fig. 4. Effects of L-NAME and ODQ on PE-induced contraction in endothelium-intact mesenteric arterial rings of $\mathrm{C}$ (a) and LP (b) rats (both semilog plots). Mesenteric arterial rings were incubated in the absence or presence of L-NAME $\left(10^{-4} \mathrm{~mol} / \mathrm{l}\right)$ or ODQ $\left(10^{-5} \mathrm{~mol} / \mathrm{l}\right)$ for $30 \mathrm{~min}$ and then stimulated with increasing concentrations of $\mathrm{PE}$. PE contraction is presented as percentage of maximum PE contraction. Data points represent mean \pm SEM of measurements in 10-12 mesenteric arterial rings from 5-6 rats of each group. ${ }^{*} \mathrm{p}<0.05$ compared to $\mathrm{PE}$ in the absence of L-NAME or ODQ.

\section{Endothelium-Dependent Relaxant Responses}

In endothelium-intact vascular rings of $\mathrm{C}$ rats, $\mathrm{ACh}$ caused concentration-dependent relaxation of PE-mediated $\left(3 \times 10^{-6} \mathrm{~mol} / \mathrm{l}\right)$ contraction. The ACh-induced relaxation of the PE contraction was significantly less in LP rats than in $\mathrm{C}$ animals (fig. $5 \mathrm{a}$ ). $\mathrm{ED}_{50}$ of $\mathrm{ACh}$ in mesenteric arterial rings of LP rats $(6.1 \pm 0.11 \mathrm{~mol} / \mathrm{l})$ was significantly different from that in arterial rings of $\mathrm{C}$ rats $(6.7 \pm 0.18 \mathrm{~mol} / \mathrm{l})$ (table 2). Because the mesenteric arte- 


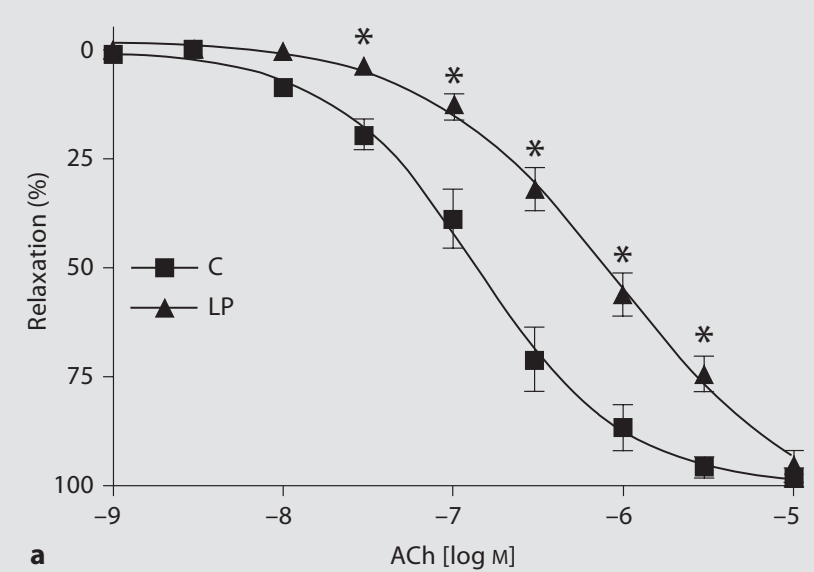

Fig. 5. a ACh-induced relaxation of PE contraction in endothelium-intact mesenteric arteries of $\mathrm{C}$ and LP rats. ACh-induced relaxation of $\mathrm{PE}$ contraction in the absence or presence of L-NAME (b) or ODQ (c) in C rats and LP rats (all semilog plots). Mesenteric rings were incubated in the absence or presence of L-NAME $\left(10^{-4} \mathrm{~mol} / \mathrm{l}\right)$ or ODQ $\left(10^{-5} \mathrm{~mol} / \mathrm{l}\right)$ for $30 \mathrm{~min}$. Submaximal PE contraction was elicited, ACh was added and then the percentage of relaxation to $\mathrm{PE}$ contraction was measured. Data points represent means \pm SEM of measurements in 10-12 mesenteric arterial rings from $5-6$ rats of each group. * $\mathrm{p}<0.05$ compared to the $\mathrm{C}$ group.
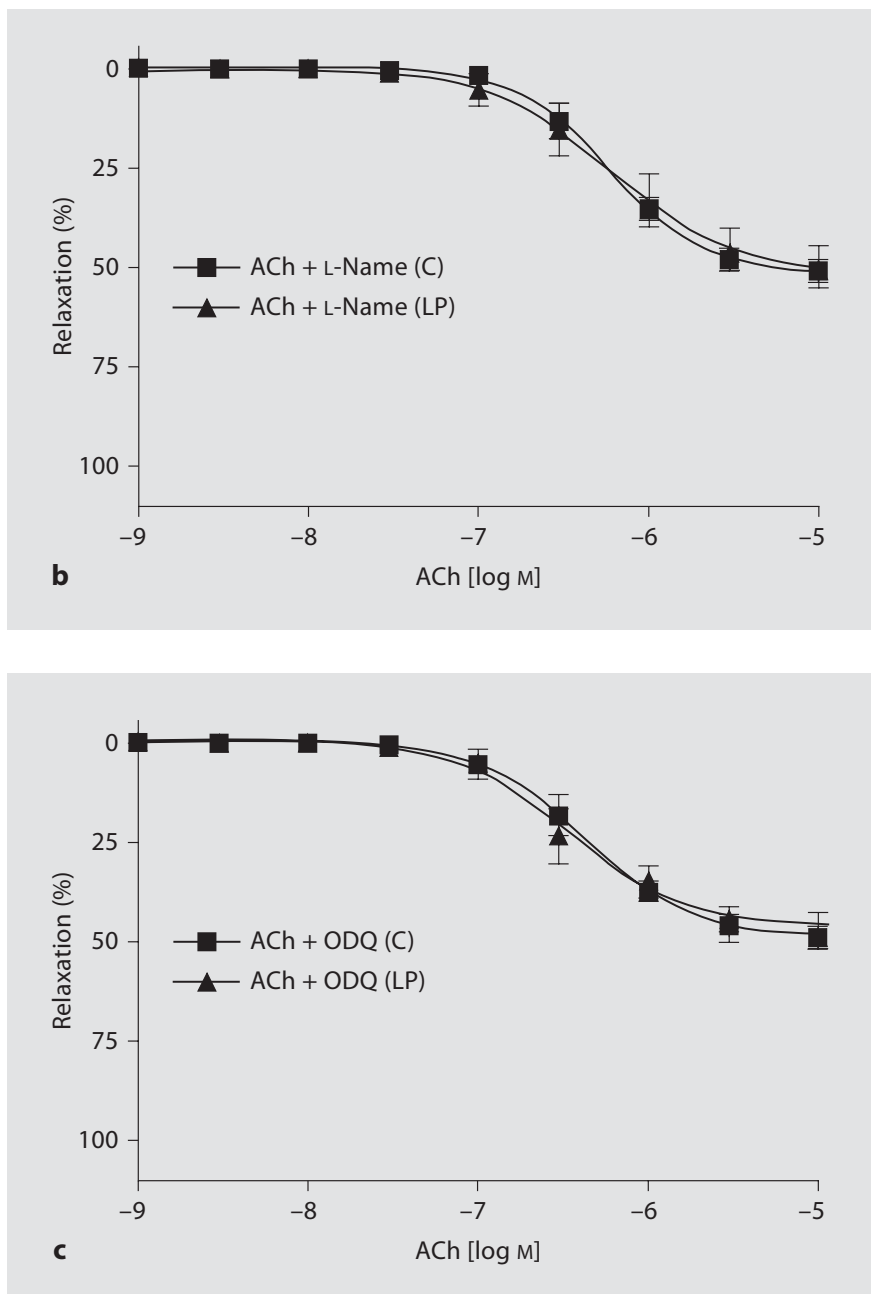

Table 2. Vascular function in offspring of the C and LP group at 1 year of age

\begin{tabular}{|c|c|c|c|c|}
\hline & \multicolumn{2}{|l|}{ C group } & \multicolumn{2}{|l|}{ LP group } \\
\hline & $\mathrm{pD}_{2}$ & $\mathrm{E}_{\max }$ & $\mathrm{pD}_{2}$ & $\mathrm{E}_{\max }$ \\
\hline $\mathrm{PE}$ & $5.42 \pm 0.054$ & 100 & $5.84 \pm 0.122^{\mathrm{a}}$ & 100 \\
\hline PE + L-NAME & $5.98 \pm 0.072^{b}$ & $136.63 \pm 5.95^{\mathrm{b}}$ & $5.97 \pm 0.077$ & $116.63 \pm 2.54^{\mathrm{a}, \mathrm{b}}$ \\
\hline $\mathrm{PE}+\mathrm{ODQ}$ & $5.86 \pm 0.028^{b}$ & $136.45 \pm 5.73^{b}$ & $6.01 \pm 0.060$ & $119.73 \pm 3.18^{\mathrm{a}, \mathrm{b}}$ \\
\hline $\mathrm{ACh}$ & $6.73 \pm 0.178$ & $98.3 \pm 1.12$ & $6.10 \pm 0.105^{\mathrm{a}}$ & $92.1 \pm 3.88$ \\
\hline $\mathrm{ACh}+\mathrm{L}-\mathrm{NAME}$ & - & $50.8 \pm 2.68^{c}$ & - & $50.0 \pm 5.40^{c}$ \\
\hline $\mathrm{ACh}+\mathrm{ODQ}$ & - & $48.7 \pm 3.15^{c}$ & - & $45.9 \pm 3.18^{c}$ \\
\hline SNP & $7.72 \pm 0.073$ & $98.0 \pm 1.06$ & $7.68 \pm 0.092$ & $99.0 \pm 0.70$ \\
\hline
\end{tabular}

Values are expressed as mean \pm SEM of 10-12 mesenteric arterial rings from 5-6 rats in each group. $\mathrm{ED}_{50}$ is presented as $-\log [\mathrm{mol} / \mathrm{l}]$ and maximal responses $\left(\mathrm{E}_{\max }\right)$ are presented as percent of maximal contraction or relaxation. $\mathrm{pD}_{2}=$ Negative log-molar concentration. ${ }^{\mathrm{a}} \mathrm{p}<0.05$ compared to the $\mathrm{C}$ group; ${ }^{\mathrm{b}} \mathrm{p}<0.05$ compared to $\mathrm{PE}$ alone in their respective groups; ${ }^{\mathrm{c}} \mathrm{p}<0.05$ compared to $\mathrm{ACh}$ alone in their respective groups. 


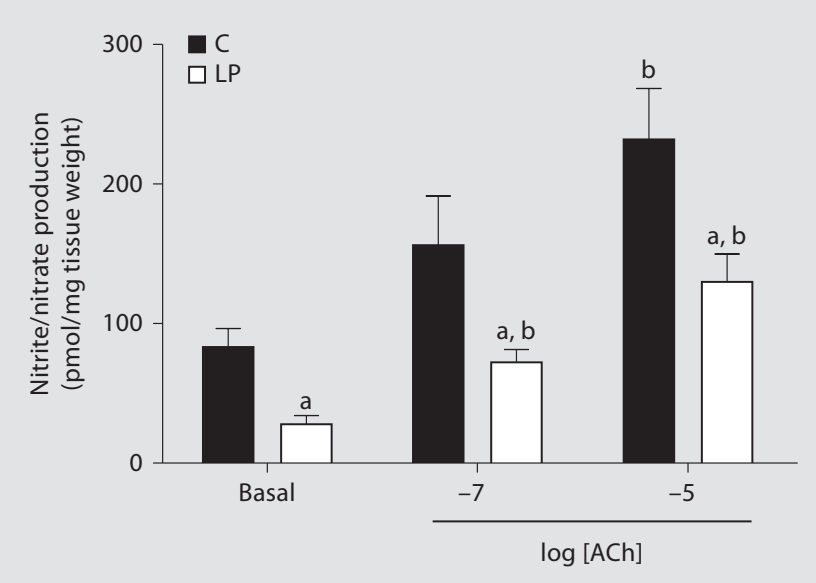

Fig. 6. Basal and ACh-induced $\mathrm{NO}_{\mathrm{x}}$ productions in endotheliumintact mesenteric arteries of $\mathrm{C}$ and LP rats. Data points represent mean \pm SEM of measurements in 30-40 mesenteric arterial rings from 3 rats of each group. ${ }^{a} p<0.05$ compared with the respective treatment in the $\mathrm{C}$ group. ${ }^{\mathrm{b}} \mathrm{p}<0.05$ compared to basal level in the respective group.

rial rings of $\mathrm{LP}$ rats showed greater vascular contraction compared to $\mathrm{C}$ rats, control experiments were performed on rings from LP rats in which the initial PE concentration was lowered to $1 \times 10^{-6} \mathrm{~mol} / \mathrm{l}$ to produce a submaximal contraction that was roughly equal in magnitude to the contraction observed in rings of $C$ rats precontracted with $3 \times 10^{-6} \mathrm{~mol} / \mathrm{l} \mathrm{PE}$. These experiments showed that the $\mathrm{ED}_{50}$ of $\mathrm{ACh}$ in mesenteric arterial rings of LP rats precontracted with $1 \times 10^{-6} \mathrm{~mol} / \mathrm{l} \mathrm{PE}(6.2 \pm 0.12 \mathrm{~mol} / \mathrm{l})$ was not significantly different from that in arterial rings precontracted with $3 \times 10^{-7} \mathrm{~mol} / \mathrm{l} \mathrm{PE}(6.1 \pm 0.11 \mathrm{~mol} / \mathrm{l})$. This shows that ACh relaxation does not vary with the amplitude of PE contractions.

Pretreatment of endothelium-intact rings with LNAME to inhibit eNOS or ODQ to inhibit cGMP production in smooth muscle inhibited ACh-induced relaxation significantly in LP and C rats (fig. 5b, c, table 2). Removal of the endothelium completely inhibited the ACh-induced relaxation to $\mathrm{PE}$ contraction in all groups of rats (data not shown).

\section{Nitrite Production}

In endothelium-intact vascular rings, the basal nitrite/ nitrate $\left(\mathrm{NO}_{\mathrm{x}}\right)$ production was $83.9 \pm 12.51 \mathrm{pmol} / \mathrm{mg}$ tissue weight in $\mathrm{C}$ rats and this was significantly lower in the LP rats (28.2 $\pm 6.37 \mathrm{pmol} / \mathrm{mg}$ tissue weight) (fig. 6). Sim-

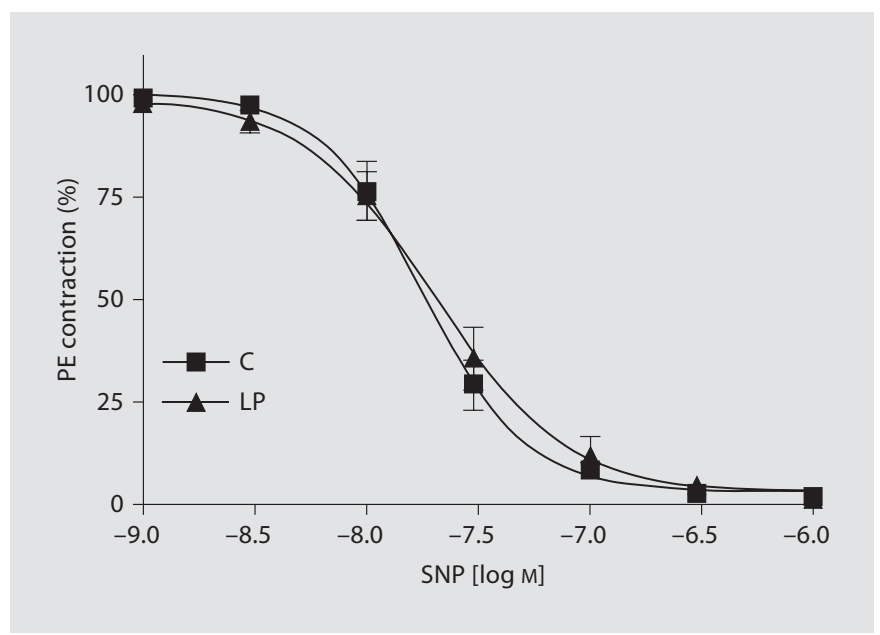

Fig. 7. SNP-induced relaxation to PE contraction in endotheliumdenuded vascular rings of C and LP rats (semilog plot). Submaximal PE contraction was elicited, increasing concentrations of SNP were added and then the percentage of relaxation to PE contraction was measured. Data points represent means \pm SEM of measurements in 10-12 mesenteric arterial rings from 5-6 rats of each group.

ilarly, $\mathrm{NO}_{\mathrm{x}}$ production in response to $\mathrm{ACh}$ was also significantly reduced in the LP group compared with the $\mathrm{C}$ group (fig. 6).

\section{Endothelium-Independent Relaxant Responses}

In endothelium-denuded vascular rings of both LP and $\mathrm{C}$ groups, SNP, an exogenous NO donor and a standard guanylate cyclase activator, caused concentrationdependent relaxation of submaximal PE contractions. The SNP-induced relaxation to PE contractions was not significantly different in vascular rings from $\mathrm{C}$ and LP rats ( $7.7 \pm 0.07$ vs. $7.7 \pm 0.09 \mathrm{~mol} / \mathrm{l}$; fig. 7 , table 2$)$.

\section{Discussion}

The goal of the present study was to determine whether dietary protein restriction during gestation resulted in hypertensive female offspring that exhibit impaired endothelium-dependent vascular relaxation and enhanced vascular contraction. Terminal studies were done in female offspring at 1 year of age. The main findings are as follows: (1) birth weight and later growth are significantly lower in LP offspring compared to the C group; (2) LP offspring have extended estrous cycle lengths with a reduced number of animals cycling; (3) MAP is elevated in 
the offspring of LP compared to C rats; (4) PE-induced contraction is enhanced in vivo and in vitro in mesenteric arteries from LP rats; (5) the endothelium-dependent vascular relaxation is reduced in LP compared with $\mathrm{C}$ rats, and (6) the reduced vascular relaxation and enhanced vascular contraction in LP rats appear to involve dysfunction of the endothelium.

CV disorders such as hypertension and coronary heart disease have been related to low birth weight or smallness at birth. In the present study, feeding dams on a low-protein diet during pregnancy gave birth to offspring with a significantly reduced birth weight compared with controls. Previous studies on dietary restriction produced variable results on birth weight. In some investigations, birth weight was reduced $[34,35]$, in others unchanged [7, $10,14,36$ ] and in some even increased [37]. The discrepancies may be due to factors that may alter response of the mother and fetus to nutrient restriction such as strain, maternal age and differences in the diets.

Similar to previous studies using protein restriction during pregnancy $[13,27]$, MAP was found to be significantly elevated in LP compared with $\mathrm{C}$ offspring in the present study. However, in contrast to our findings, some studies reported that female offspring do not develop hypertension $[24,25]$. Differences in protocols, e.g. severity and duration of undernutrition or vascular bed studied, may account for the variable results obtained for each model. In some instances, vascular dysfunction may not be accompanied with increased pressor responses as observed in female offspring of global diet-restricted pregnant rats [38]. In view of the differences in the protocols used, direct comparisons between models should be treated with caution. For example, Woods et al. [24] used $50 \%$ protein restriction that resulted in a reduction of about $10 \%$ in birth weight, whereas we used a diet with $66 \%$ protein restriction that resulted in a reduction of $30 \%$ in birth weight. It is possible that a severer or a more extended maternal dietary restriction (i.e. into the lactation period, during which nephrogenesis continues) would lead to consistent hypertension in female offspring. In agreement with our findings, there are reports of hypertension and reduced nephron number in female offspring of more severely protein-restricted dams [25, 31]. Indeed, in one study in women, the inverse association between birth weight and adult hypertension or cardiovascular disease was marked only in the lowest birth weight category, which represented birth weights more than $25 \%$ below average $[39,40]$. Thus, it appears that the resistance of females to the hypertensive effects of perinatal insults breaks down when the insults are severer.
In order to investigate alterations of vascular function in the female offspring of protein-restricted dams, responses to $\mathrm{ACh}$, an endothelium-dependent vasodilator, to SNP, an endothelium-independent vasodilator, and to $\mathrm{PE}$, a vasoconstrictor whose effects are modulated by the endothelium, were investigated. Hypotensive responses and mesenteric vasorelaxation to ACh were reduced in LP offspring compared to $\mathrm{C}$ rats, but no differences could be detected to SNP. These observations suggest that it is not the smooth-muscle vasodilating capability that is reduced in LP offspring but some function related to the endothelium. Reports of impaired endothelial function in female offspring have been shown in previous studies using excess fat $[41,42]$ and global food restriction during pregnancy [38]. In fact, Goodfellow et al. [43] and Leeson et al. [44] demonstrated that growth restriction in human pregnancy is associated with endothelial dysfunction.

Considering that NO is the main agonist responsible for endothelial-dependent relaxation, we characterized the relative contribution of $\mathrm{NO}$ in vasodilation of mesenteric arteries isolated from LP and C offspring. Besides $\mathrm{NO}$, ACh also induces vasorelaxation through NO-independent mechanisms [45-48]. This is evident in this study by the observation that L-NAME and ODQ did not completely inhibit ACh-induced relaxation. However, this L-NAME/ODQ-resistant component was shown to contribute equally to vasodilation in both $\mathrm{C}$ and LP offspring, indicating that only the $\mathrm{NO}$ component may be impaired, thereby contributing to the observed difference in pressor response in these groups. Although endothelium-derived hyperpolarizing factor is known to compensate for loss of NO function in arteries [48], such a response was not observed in this study.

Impaired NO function may be due to decreased $\mathrm{NO}$ synthesis and/or bioavailability. The finding that LNAME induced a greater increase in MAP in C than in LP offspring indicates that NO-mediated control of vascular tone is certainly compromised in female offspring exposed to protein restriction in utero. Consistent with this finding, pretreatment of the isolated mesenteric arteries from $\mathrm{C}$ rats with L-NAME inhibited ACh-induced vascular relaxation to a greater extent than in LP offspring. These results indicate that NO synthesis by endothelial cells may be impaired in LP rats. This concept is supported by the observation that both basal and AChinduced $\mathrm{NO}_{\mathrm{x}}$ productions were significantly reduced in arteries from the LP compared with C rats. There are similar reports of reduced basal and agonist-induced $\mathrm{NO}$ release in pregnant rat dams fed a protein-restricted diet [49] and also in the offspring of patients with essential 
hypertension [50]. The decreased levels of NO may be associated with decreased expression/activity of eNOS as previously reported by us and others $[13,51]$, or due to rapid degradation by superoxide [52]. However, our attempt to determine eNOS activity in mesenteric arteries of LP rats in this study showed varied responses and was less conclusive, necessitating further investigation.

It is well known that the endothelium modulates the vasoconstrictor response to $\mathrm{PE}$, probably by releasing NO. Reduced NO function may lead to increased responses to PE. The fact that the LP offspring were hyperresponsive to $\mathrm{PE}$ and that the mesenteric arteries with endothelium from LP rats were more responsive to PE led us to suggest that the modulatory role of the endothelium on the vascular responses has been lost in rats submitted to intrauterine protein restriction. The findings that $\mathrm{L}$ NAME and ODQ pretreatment potentiated PE-induced contraction in mesenteric arteries from $\mathrm{C}$ rats but had minimal effects in LP offspring also suggest that the vascular smooth muscle responses to $\mathrm{PE}$ have been preserved in LP offspring, reinforcing the hypothesis that protein restriction in utero mainly affects the endothelium.

The factors that contribute to endothelial dysfunction in LP offspring remain unclear. In LP offspring, the reproductive performance was shown to be impaired during adult life (i.e. after 6 months) as evident by increased estrous cycle length and decreased number of cycling animals. Similar findings of reduced reproductive function associated with delayed vaginal opening, onset of first estrous and impaired endocrine function in offspring of nutrient-restricted dams were reported [53]. We and others have reported that, consistent with the impaired reproductive function, the serum estrogen levels in rats exposed to intrauterine undernutrition are only half of those of controls $[13,27,54]$. Estrogen is known to have a vasoprotective effect on endothelium via an NO-mediated mechanism. It was shown that long-term treatment of cultured human and bovine endothelial cells with estrogen upregulates eNOS activity $[30,55]$. In addition, deficiency of estrogen (following ovariectomy) in spontaneously hypertensive rats causes a reduction in endothelial function [56]. Since females from dams submitted to protein restriction during pregnancy exhibited reduced estrogen levels, we suggested that the vasoprotective role of the estrogen on the vascular responses may be lost, leading to decreased endothelial function. Not only physiologically relevant concentrations of estrogen are important, but also having active estrogen receptors (ERs; including ER $\alpha$ and $E R \beta$ ) is essential for both a rapid and long-term positive CV effect [57-60]. We have previously demonstrated a decrease in ER $\alpha$ and ER $\beta$ in the thoracic aorta of protein-restricted female offspring [51]. In fact, preliminary studies from our laboratory have shown that ovariectomy exacerbates hypertension in the offspring of protein-restricted dams, indicating a role for estrogen in the normalization of blood pressure. Further studies are under way to delineate the vasoprotective mechanisms of estrogen.

Several previous studies have demonstrated that essential hypertension is associated with impaired endothelium-dependent vascular relaxation [61-63]. However, whether this is a primary or secondary abnormality is unknown. Certain previous investigations have suggested that endothelial dysfunction is a primary defect in essential hypertension, present even before the clinical documentation of elevated blood pressure [64]. On the other hand, certain observations suggest that endothelial dysfunction may occur as a consequence rather than a cause of elevated blood pressure. In particular, human studies and several animal models of induced hypertension, including suprarenal coarctation of the abdominal aorta in rabbits [65], salt-induced hypertension in Dahl salt-sensitive rats [66], and pressure increases in cat cerebral [67] and dog coronary arteries [68], have all shown a selective impairment of endothelium-dependent vasodilation after elevations in blood pressure. It is important to emphasize the following cautionary remarks regarding the aforementioned interpretations. First, although we hypothesized that the decreased endothelial cell function and increased vascular contraction in LP rats could contribute to the observed elevation in arterial pressure, the reverse is also plausible. Further analysis of the time course of the changes in vascular functions and the increase in arterial pressure in rats $<1$ year of age should help determine whether the relation between these two parameters is causal or associative. Second, although the reduction in vascular relaxation and increase in vascular contraction in the LP group could explain in part the increase in arterial pressure, other factors such as renal, neural and hormonal control mechanisms of arterial pressure could also be involved. Third, as the vascular endothelium also releases contracting factors such as thromboxane and endothelin, we cannot exclude a role for these factors in the endothelial dysfunction induced by intrauterine undernutrition. Therefore, analysis of the role of other endothelium-derived relaxing factors in the vasculature and blood pressure changes observed in LP rats should be carefully examined in future studies.

In summary, the present study has shown that an endothelium-dependent vascular relaxation pathway involving the release of $\mathrm{NO}$ from endothelial cells, but not 
the smooth muscle response to NO, is inhibited in systemic vessels of LP offspring of pregnant rats with reduced protein intake. The decreased NO-mediated vascular relaxation pathway in LP rats might explain the increased vascular contraction and arterial pressure in young adult rats with low birth weight.

\section{Acknowledgement}

Financial support from National Institutes of Health through grants No. HL-58144 and HL-72650 is greatly appreciated.

\section{References}

1 Phillips DI, Barker DJ, Hales CN, Hirst S, Osmond C: Thinness at birth and insulin resistance in adult life. Diabetologia 1994;37:150154.

-2 Barker DJ, Osmond C, Forsen TJ, Kajantie E, Eriksson JG: Trajectories of growth among children who have coronary events as adults. N Engl J Med 2005;353:1802-1809.

- 3 Eriksson JG, Forsen T, Tuomilehto J, Osmond C, Barker DJ: Early growth and coronary heart disease in later life: longitudinal study. BMJ 2001;322:949-953.

4 Forsen T, Osmond C, Eriksson JG, Barker DJ: Growth of girls who later develop coronary heart disease. Heart 2004;90:20-24.

5 Baker JL, Olsen LW, Sorensen TI: Childhood body-mass index and the risk of coronary heart disease in adulthood. N Engl J Med 2007;357:2329-2337.

-6 Barker DJ, Bull AR, Osmond C, Simmonds SJ: Fetal and placental size and risk of hypertension in adult life. BMJ 1990;301:259-262.

7 Langley-Evans SC, Phillips GJ, Jackson AA: In utero exposure to maternal low-protein diets induces hypertension in weanling rats, independently of maternal blood pressure changes. Clin Nutr 1994;13:319-324.

$\$ 8$ Langley-Evans SC: Critical differences between two low-protein diet protocols in the programming of hypertension in the rat. Int J Food Sci Nutr 2000;51:11-17.

-9 Lewis RM, Forhead AJ, Petry CJ, Ozanne SE, Hales CN: Long-term programming of blood pressure by maternal dietary iron restriction in the rat. Br J Nutr 2002;88:283-290.

-10 Torrens C, Brawley L, Barker AC, Itoh S, Poston L, Hanson MA: Maternal protein restriction in the rat impairs resistance artery but not conduit artery function in pregnant offspring. J Physiol 2003;547:77-84.

-11 Gluckman PD, Hanson MA: Living with the past: evolution, development, and patterns of disease. Science 2004;305:1733-1736.

12 Alexander BT: Fetal programming of hypertension. Am J Physiol Regul Integr Comp Physiol 2006;290:R1-R10.

$\checkmark 13$ Franco Mdo C, Arruda RM, Dantas AP, Kawamoto EM, Fortes ZB, Scavone C, Carvalho $\mathrm{MH}$, Tostes RC, Nigro D: Intrauterine undernutrition: expression and activity of the endothelial nitric oxide synthase in male and female adult offspring. Cardiovasc Res 2002;56:145-153.
14 Brawley L, Itoh S, Torrens C, Barker A, Ber- 24 Woods LL, Ingelfinger JR, Rasch R: Modest tram C, Poston L, Hanson M: Dietary protein restriction in pregnancy induces hypertension and vascular defects in rat male offspring. Pediatr Res 2003;54:83-90. maternal protein restriction fails to program adult hypertension in female rats. Am J Physiol Regul Integr Comp Physiol 2005; 289:R1131-R1136.

15 Langley-Evans SC, Jackson AA: Captopril $\longrightarrow 25$ Woods LL, Weeks DA, Rasch R: Programnormalises systolic blood pressure in rats ming of adult blood pressure by maternal with hypertension induced by fetal expo- protein restriction: role of nephrogenesis. sure to maternal low-protein diets. Comp Kidney Int 2004;65:1339-1348.

Biochem Physiol A Physiol 1995;110:223- 26 Ojeda NB, Grigore D, Robertson EB, Alex228.

16 Sherman RC, Langley-Evans SC: Early administration of angiotensin-converting enzyme inhibitor captopril prevents the development of hypertension programmed by intrauterine exposure to a maternal low-protein diet in the rat. Clin Sci (Lond) 1998;94: 373-381.

17 Sahajpal V, Ashton N: Renal function and angiotensin $\mathrm{AT}_{1}$ receptor expression in young rats following intrauterine exposure to a maternal low-protein diet. Clin Sci (Lond) 2003;104:607-614.

18 Nwagwu MO, Cook A, Langley-Evans SC: Evidence of progressive deterioration of renal function in rats exposed to a maternal low-protein diet in utero. Br J Nutr 2000;83: $79-85$.

19 Gardner DS, Jackson AA, Langley-Evans SC: Maintenance of maternal diet-induced hypertension in the rat is dependent on glucocorticoids. Hypertension 1997;30:15251530.

20 Woods LL: Maternal glucocorticoids and prenatal programming of hypertension. Am J Physiol Regul Integr Comp Physiol 2006; 291:R1069-R1075.

21 Hadoke PW, Lindsay RS, Seckl JR, Walker BR, Kenyon CJ: Altered vascular contractility in adult female rats with hypertension programmed by prenatal glucocorticoid exposure. J Endocrinol 2006;188:435-442.

22 Pechere-Bertschi A, Burnier M: Female sex hormones, salt, and blood pressure regulation. Am J Hypertens 2004;17:994-1001.

23 Ozaki T, Nishina H, Hanson MA, Poston L: Dietary restriction in pregnant rats causes gender-related hypertension and vascular dysfunction in offspring. J Physiol 2001;530: 141-152. ander BT: Estrogen protects against increased blood pressure in postpubertal female growth-restricted offspring. Hypertension 2007;50:679-685.

27 Gangula PR, Reed L, Yallampalli C: Antihypertensive effects of flutamide in rats that are exposed to a low-protein diet in utero. Am J Obstet Gynecol 2005;192:952-960.

28 Sudoh N, Toba K, Akishita M, Ako J, Hashimoto M, Iijima K, Kim S, Liang YQ, Ohike Y, Watanabe T, Yamazaki I, Yoshizumi M, Eto M, Ouchi Y: Estrogen prevents oxidative stress-induced endothelial cell apoptosis in rats. Circulation 2001;103:724-729.

29 Santos RL, Abreu GR, Bissoli NS, Moyses MR: Endothelial mediators of $17 \beta$-estradiolinduced coronary vasodilation in the isolated rat heart. Braz J Med Biol Res 2004;37: 569-575.

30 Selles J, Polini N, Alvarez C, Massheimer V: Progesterone and $17 \beta$-estradiol acutely stimulate nitric oxide synthase activity in rat aorta and inhibit platelet aggregation. Life Sci 2001;69:815-827.

31 Vehaskari VM, Aviles DH, Manning J: Prenatal programming of adult hypertension in the rat. Kidney Int 2001;59:238-245.

32 Sankaralingam S, Desai KM, Wilson TW: Clofibrate acutely reverses saline-induced endothelial dysfunction: role of calcium-activated potassium channels. Am J Hypertens 2006;19:1167-1173.

33 Ross GR, Yallampalli C: Vascular hyperresponsiveness to adrenomedullin during pregnancy is associated with increased generation of cyclic nucleotides in rat mesenteric artery. Biol Reprod 2007;76:118-123.

34 Galler JR, Tonkiss J: Prenatal protein malnutrition and maternal behavior in SpragueDawley rats. J Nutr 1991;121:762-769. 
- 35 Vickers MH, Reddy S, Ikenasio BA, Breier $\mathrm{BH}$ : Dysregulation of the adipoinsular axis - a mechanism for the pathogenesis of hyperleptinemia and adipogenic diabetes induced by fetal programming. J Endocrinol 2001;170:323-332.

- 36 Lamireau D, Nuyt AM, Hou X, Bernier S, Beauchamp M, Gobeil F Jr, Lahaie I, Varma DR, Chemtob S: Altered vascular function in fetal programming of hypertension. Stroke 2002;33:2992-2998.

-37 Langley-Evans SC, Gardner DS, Jackson AA: Association of disproportionate growth of fetal rats in late gestation with raised systolic blood pressure in later life. J Reprod Fertil 1996;106:307-312.

- 38 Holemans K, Gerber R, Meurrens K, De Clerck F, Poston L, Van Assche FA: Maternal food restriction in the second half of pregnancy affects vascular function but not blood pressure of rat female offspring. $\mathrm{Br} \mathrm{J}$ Nutr 1999;81:73-79.

- 39 Rich-Edwards JW, Stampfer MJ, Manson JE, Rosner B, Hankinson SE, Colditz GA, Willett WC, Hennekens $\mathrm{CH}$ : Birth weight and risk of cardiovascular disease in a cohort of women followed up since 1976. BMJ 1997; 315:396-400.

-40 Curhan GC, Chertow GM, Willett WC, Spiegelman D, Colditz GA, Manson JE, Speizer FE, Stampfer MJ: Birth weight and adult hypertension and obesity in women. Circulation 1996;94:1310-1315.

41 Taylor PD, Khan IY, Hanson MA, Poston L: Impaired EDHF-mediated vasodilatation in adult offspring of rats exposed to a fat-rich diet in pregnancy. J Physiol 2004;558:943951.

42 Khan IY, Dekou V, Douglas G, Jensen R, Hanson MA, Poston L, Taylor PD: A high-fat diet during rat pregnancy or suckling induces cardiovascular dysfunction in adult offspring. Am J Physiol Regul Integr Comp Physiol 2005;288:R127-R133.

-43 Goodfellow J, Bellamy MF, Gorman ST, Brownlee M, Ramsey MW, Lewis MJ, Davies DP, Henderson AH: Endothelial function is impaired in fit young adults of low birth weight. Cardiovasc Res 1998;40:600-606.

-44 Leeson CP, Whincup PH, Cook DG, Donald AE, Papacosta O, Lucas A, Deanfield JE: Flow-mediated dilation in 9- to 11-year-old children: the influence of intrauterine and childhood factors. Circulation 1997;96: 2233-2238.

45 Meng W, Ma J, Ayata C, Hara H, Huang PL, Fishman MC, Moskowitz MA: ACh dilates pial arterioles in endothelial and neuronal NOS knockout mice by NO-dependent mechanisms. Am J Physiol 1996;271:H1145H1150.
46 Huang A, Sun D, Smith CJ, Connetta JA, Shesely EG, Koller A, Kaley G: In eNOS knockout mice skeletal muscle arteriolar dilation to acetylcholine is mediated by EDHF. Am J Physiol Heart Circ Physiol 2000;278: H762-H768.

47 Sun D, Huang A, Smith CJ, Stackpole CJ, Connetta JA, Shesely EG, Koller A, Kaley G: Enhanced release of prostaglandins contributes to flow-induced arteriolar dilation in eNOS knockout mice. Circ Res 1999;85:288 293.

48 Desai KM, Gopalakrishnan V, Hiebert LM, McNeill JR, Wilson TW: EDHF-mediated rapid restoration of hypotensive response to acetylcholine after chronic, but not acute, nitric oxide synthase inhibition in rats. Eur J Pharmacol 2006;546:120-126.

49 Brawley L, Torrens C, Itoh S, Barker AC, Poston L, Clough GF, Hanson MA: Dietary protein restriction attenuates acetylcholineinduced nitric oxide levels in small mesenteric arteries from pregnant rat dams. FASEB J 2002;16:A104.

50 McAllister AS, Atkinson AB, Johnston GD, Hadden DR, Bell PM, McCance DR: Basal nitric oxide production is impaired in offspring of patients with essential hypertension. Clin Sci (Lond) 1999;97:141-147.

51 Gangula PR, Reed L, Yallampalli C: In utero low-protein diet alters vascular estrogen receptors and endothelial nitric oxide levels in adult offspring. J Soc Gynecol Invest 2005; 12:161A.

$\checkmark 52$ Franco Mdo C, Dantas AP, Akamine EH, Kawamoto EM, Fortes ZB, Scavone C, Tostes RC, Carvalho MH, Nigro D: Enhanced oxidative stress as a potential mechanism underlying the programming of hypertension in utero. J Cardiovasc Pharmacol 2002;40: 501-509.

53 Guzman C, Cabrera R, Cardenas M, Larrea F, Nathanielsz PW, Zambrano E: Protein restriction during fetal and neonatal development in the rat alters reproductive function and accelerates reproductive ageing in $\mathrm{fe}$ male progeny. J Physiol 2006;572:97-108.

54 Borwick SC, Rhind SM, McMillen SR, Racey PA: Effect of undernutrition of ewes from the time of mating on fetal ovarian development in mid gestation. Reprod Fertil Dev 1997;9: 711-715.

55 Tolbert T, Thompson JA, Bouchard P, Oparil $\mathrm{S}$ : Estrogen-induced vasoprotection is independent of inducible nitric oxide synthase expression: evidence from the mouse carotid artery ligation model. Circulation 2001;104: $2740-2745$.
6 Dantas AP, Scivoletto R, Fortes ZB, Nigro D, Carvalho MH: Influence of female sex hormones on endothelium-derived vasoconstrictor prostanoid generation in microvessels of spontaneously hypertensive rats. Hypertension 1999;34:914-919.

57 Mendelsohn ME, Karas RH: Molecular and cellular basis of cardiovascular gender differences. Science 2005;308:1583-1587.

58 Xue B, Pamidimukkala J, Lubahn DB, Hay M: Estrogen receptor-alpha mediates estrogen protection from angiotensin II-induced hypertension in conscious female mice. Am J Physiol Heart Circ Physiol 2007;292: H1770-H1776.

-59 Huang A, Kaley G: Gender-specific regulation of cardiovascular function: estrogen as key player. Microcirculation 2004;11:9-38.

60 Pare G, Krust A, Karas RH, Dupont S, Aronovitz M, Chambon P, Mendelsohn ME: Estrogen receptor- $\alpha$ mediates the protective effects of estrogen against vascular injury. Circ Res 2002;90:1087-1092.

61 Panza JA, Quyyumi AA, Brush JE Jr, Epstein SE: Abnormal endothelium-dependent vascular relaxation in patients with essential hypertension. N Engl J Med 1990;323:2227.

-62 Linder L, Kiowski W, Buhler FR, Luscher TF: Indirect evidence for release of endothelium-derived relaxing factor in human forearm circulation in vivo. Blunted response in essential hypertension. Circulation 1990;81: 1762-1767.

63 Taddei S, Virdis A, Mattei P, Salvetti A: Vasodilation to acetylcholine in primary and secondary forms of human hypertension. Hypertension 1993;21:929-933.

64 Taddei S, Virdis A, Mattei P, Arzilli F, Salvetti $A$ : Endothelium-dependent forearm vasodilation is reduced in normotensive subjects with familial history of hypertension. J Cardiovasc Pharmacol 1992;20(suppl 12): S193-S195.

65 Miller MJ, Pinto A, Mullane KM: Impaired endothelium-dependent relaxations in rabbits subjected to aortic coarctation hypertension. Hypertension 1987; 10:164-170.

- 66 d'Uscio LV, Barton M, Shaw S, Moreau P, Luscher TF: Structure and function of small arteries in salt-induced hypertension: effects of chronic endothelin-subtype-A-receptor blockade. Hypertension 1997;30:905-911.

- 67 Harder DR, Sanchez-Ferrer C, Kauser K, Stekiel WJ, Rubanyi GM: Pressure releases a transferable endothelial contractile factor in cat cerebral arteries. Circ Res 1989;65:193198.

-68 De Bruyn VH, Nuno DW, Cappelli-Bigazzi M, Dole WP, Lamping KG: Effect of acute hypertension in the coronary circulation: role of mechanical factors and oxygen radicals. J Hypertens 1994;12:163-172. 